Genç Ersoy, B. (2021). Türkçe öğretiminde eğitsel oyun kullanımı: Bir meta-tematik analiz çalışması. Ana Dili Eğitimi Dergisi, 9(2), 510-530.

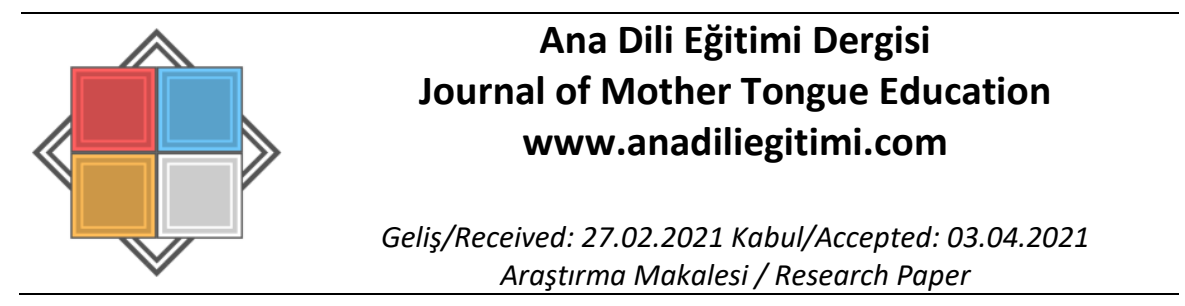

Türkçe Öğretiminde Eğitsel Oyun Kullanımı: Bir Meta-Tematik Analiz Çalışması

\author{
Berrin GENÇ ERSOY**
}

\begin{abstract}
Öz
Çalışmanın amacı eğitsel oyun kullanımın Türkçe öğretimine etkisini meta-tematik analiz çerçevesinde belirlemektir. Bu amaç doğrultusunda Google Scholar, Yükseköğretim Kurulu Tez Merkezi, Ulakbim TR Dizin, Web of Sience, Eric ve Proquest veri tabanlarından Türkçe öğretiminde eğitsel oyun konusunda gerçekleştirilmiş 13 nitel çalışma araştırmaya dahil edilmiştir. Araştırma bulguları "Türkçe dersinde eğitsel oyun tekniğinin kullanımı", "öğretmen yeterliklerine etkisi, "öğrenci kazanımlarına etkisi" ve "öğretme-öğrenme sürecine etkisi" olarak temalaşmıştır. Araştırma sonuçları Türkçe öğretiminde eğitsel oyun kullanımının öğrenci kazanımlarına ve öğretme öğrenme sürecine olumlu etkilerinin olduğunu öğretmen, öğrenci ve veli boyutundan sunmaktadır. Ayrıca sonuçlar öğretmenlerin eğitsel oyun kullanımındaki yeterliklerinden ziyade teknik kullanımındaki yetersizliklerinin ön plana çıktığını göstermektedir. Araştırma sonunda eğitsel oyunların Türkçe öğretiminde kullanımına yönelik nitel veriye sahip araştırmalara gereksinim olduğu, eğitsel oyun tekniğinin etkileri üzerine özellikle dil becerileri bağlamında derinlemesine ve boylamsal araştırmalar gerçekleştirilmesi önerilmektedir.
\end{abstract}

Anahtar Kelimeler: Türkçe öğretimi, eğitsel oyun, meta-tematik analiz, içerik analizi

The Use of Educational Games in Teaching Turkish: A Meta -Thematic Analysis Abstract

This study aims to determine the effects of using educational games on Turkish instruction through meta-thematic analysis. 13 qualitative studies from Google Scholar, Higher Education Board Thesis Center, Ulakbim TR Index, Web of Science, ERIC, and ProQuest databases were included in the study. Data were analyzed through content analysis, and themes and sub-themes were created. The findings were themed as using the educational game method in the Turkish course, and the effects of using games on teacher competencies, student achievement, and the teaching-learning process. The data obtained from teachers, students, and parents show that using educational games in teaching Turkish positively affects student achievement and the teaching-learning process. The results also reveal teachers' lack of competence in using the method. Based on the findings, it is recommended that more in-depth and longitudinal qualitative research on the effects of the method be carried out.

Keywords: Teaching Turkish, educational games, meta-thematic analysis, content analysis

\title{
Giriş
}

Insanlığın var olduğu günden bugüne oyun kavramı ile ilgili farklı tanımlamalar yapılarak oyunun insan yaşamındaki etkileri araştırılmaya çalışılmıştır. Sanat faaliyetlerinden ticarete, eğlenceden eğitime kadar birçok farklı alanda oyun türlerinin kullanımı oyunun işlevselliğini ve farklı intiyaçları karşılama potansiyelini gözler önüne sermektedir. Oyun kavramının bu çok yönlü yapısını "oyun oynayan insan" kavramı ile açıklamaya çalışan Johan Huizinga, oyunun insan için önemini ve açıklanması zor yapısını şu sözlerle ifade etmektedir: “Oyun anlam bakımından zengin bir işlevdir. (...) Her oyun bir anlam taşır. Eğer oyuna bir öz yükleyen bu faal ilkeye zihin dersek aşırıya kaçmış oluruz;

\footnotetext{
** Dr. Öğr. Üyesi, TED Üniversitesi, Eğitim Fakültesi, Temel Eğitim Bölümü, Ankara, berringenc@gmail.com, ORCID: 0000-0003-0049-4744
} 
eğer ona içgüdü dersek hiçbir şey söylememiş oluruz." (aktaran Çakmak, 2012). "Oyun dahil eder ve serbest bırakır. Özümler. Yakalar, başka bir ifadeyle, cezbeder." (Huizinga, 2015, s.28). Oyuna yönelik bu idealize bakış açısına karşın oyuna farklı bir yaklaşımda bulunan Baltacıoğlu (1938), "Çocuk faaliyetinin en tipik şekli oyundur. (...) Oyunun hiçbir faydası yoktur demiyorum; oyun, çocuğun sosyal gelişmesine yarayacak fiziko-psişik malzemeyi hazırlar; fakat bu teşekkülün kendisi değildir.." ifadesi ile "oyunun yalnızca oyun olduğunu" vurgulamaktadır (aktaran Aytaş ve Uysal, 2017).

And'a (2019) göre ise çocuğun en önemli işi oyun, en önemli aracı ise oyuncaklarıdır. Oyunlar çocukluk döneminde ihtiyaçların karşılanmasına hizmet ederken yetişkinlikte yaratıcılık gibi üst düzey becerilerin gelişmesine katkı sağlamaktadır (Winnicott, 2013). Kişilerin çocukluk dönemlerinde dünyayı anlamlandırmada ve iletişime geçmede bir araç olan oyun (Ketterlinus, 2017) kültüre geçiş ve yetişkinler dünyasına katılımı sağlamada önemli bir yoldur (And, 1979). Oyun çocuğun dünyayı anlamlandırmasında, başkaları ile iletişime geçmesinde ve kendini ifade edebilmesinde bir araç olarak önemli bir yere sahiptir. Oyun oynama sürecinde dil ve zihinsel beceriler birlikte kullanılmaktadır. Bu durum dil becerilerinin gelişimine önemli katkılar sağlamaktadır (Güneş, 2015).

Oyunun birtakım özellikleri oyun ve dil gelişimini birbiriyle ilişkilendirir. Birçok oyun sembolik düşünceyi içermekte ve oyunlardaki gerçek nesneler sembol görevi görmektedir. Söz konusu sembol ile temsil ettiği nesne arasındaki bu ilişki, bir sözcüğün referansıyla olan ilişkisine benzemektedir. Bu da oyunların çocuklara sembolik ilişki kurma pratiği yapmalarına olanak tanıdığını göstermektedir. Oyunların dil gelişimi ile ilişkilendirilmesinde diğer özellikler ise sosyal etkileşim ve bu etkileşim sırasındaki dil girdileridir (Weisberg, vd., 2013). Çocuklar oyun sırasında kendilerini ilgilendiren şeyler hakkında konuşurlar ve konuşulanları dinlerler. Böylece yeni sözcükleri dağarcıklarına kazandırma fırsatı yakalar ve kendilerini sözel biçimlerde ifade edebilirler. Ayrıca oyun sırasında vurgu, tonlama, sesletim gibi faktörleri gözlemleme ve kendi kullanımlarına geçirme olanağına sahip olurlar.

Dil becerilerinin gelişiminde kişilerin sözlü ve yazııı dili anlamak, anladığını doğru biçimde aktarmak ve dil becerilerini kullanıma geçirebilmek için çaba sarf etmeleri gerekmektedir. Bu çaba her an gerekli olup uzun bir süre boyunca sürdürülebilir olmalıdır. Bu bağlamda oyunlar erken çocukluk ve ilkokul dönemi çocuklarının dil becerilerini geliştirmeye yönelik ilgilerini ve çabalarını sürdürebilmelerinde onları cesaretlendirerek yardımcı olma potansiyeline sahiptir (Genç-Ersoy, 2020). Bu doğrultuda dil öğretimi sürecinde oyunların işe koşulması önemli görülmektedir. Nitekim oyunların dil öğretimi sürecine önemli katkılarının olabileceği vurgulanmaktadır (Lillard, vd., 2013; Zigler ve Bishop-Josef, 2004; Valipour ve Aidinlou, 2014).

Oyunların dil öğretiminde özellikle iletişim becerileri ile okuma, konuşma, yazma ve dinleme becerilerinin geliştirilmesini desteklediği, oyun destekli dil öğretimi ortamlarında öğrenci motivasyonunun arttığı ve kalıcı öğrenmenin sağlandığı bilinmektedir. Bu kalıcılığın nedenlerinden biri, oyunun öğrenme ortamını eğlenceli hale getirmesi, bir diğeri ise dil öğretimi sürecini öğrenciler için ilginç hale getirmesidir. Araştırmalar öğrencilerin bir konuyu ilginç bulduğunda daha kolay öğrendiğini ve bu süreçte kazanılan becerilerin daha kalıcı olduğunu göstermektedir (Aydın, 2014). Dil öğretimi konuları özelinde oyun kullanımının sözlü olarak ifade edilen kavramları anlama, yeni sözcükler öğrenme, olaylarda çeşitli zaman kiplerini uygun olarak kullanma, kişi eklerini uygun olarak kullanma, soru sorma ve cevap verme, hayali durumları ifade etme, duygu ve düşünceleri anlatma ve sözcükleri doğru telaffuz edebilme gibi dil becerilerini kazandırmada etkili olduğu belirtilmektedir (Karadağ ve Çalışkan, 2005).

Eğitsel oyunlar dil öğretiminde aynı zamanda öğretimsel içerik ve süreçlerin tasarlanmasında öğretmenlere destek sağlamaktadır (Mubaslat, 2012). Ancak öğretim sürecine oyunun entegre edilmesinde önemli hususlar bulunmaktadır. Zhu (2012), dil öğretiminin yapıldığı derslerde eğitsel oyun kullanımında özellikle zamanlama, seçim, hazırlık ve yönetim gibi konularda öğretmenlerin dikkat etmeleri gereken noktaları vurgulamaktadır. Çünkü söz konusu noktalarda yapılacak olan hatalar öğretim sürecini sekteye uğratmakta bu durum öğrencileri olumsuz etkileyebilmektedir. Öğretim sürecinde eğitsel oyunu işe koşacak olan öğretmenlerin oyunun derslerde kullanımında olumsuzlukları en aza indirerek yüksek düzeyde kazanım elde edebilmeleri için öğretim sürecini öğrencinin ihtiyacına ve dersin amacına göre planlayarak hazırlık yapması, söz konusu amaç ve ihtiyaçlara uygun oyun seçimine karar vermesi, oyunun, öğrencilerin ve öğretim sürecinin yönetimi gibi konulara dikkatle 
yaklaşması gerekmektedir. Özellikle anadili ya da yabancı dil öğretiminde öğrencilerin geliştirilme gereksinimi olan dil becerileri göz önünde bulundurularak öğrencilerin sahip oldukları dil yeterlikleri dikkate alınmalı ve öğretimsel süreç bu doğrultuda yürütülmelidir.

Türkçe öğretiminde de eğitsel oyun kullanımına ilişkin birçok çalışma gerçekleştirilmiştir (Arıcı, 2017; Aşcl, 2019; Aydın, 2014; Boz, 2018; Coşkun, Akarsu ve Kariper, 2012; Gedik, 2017; İnal ve Korkmaz 2019; Kalfa, 2014; Kara ve Akın, 2018). Gerçekleştirilen çalışmalarda Türkçe öğretiminde eğitsel oyun kullanımının okuma, yazma, konuşma, dinleme, söz varlığını geliştirme gibi dil becerilerinin yanı sıra öğrencilerin akademik başarıları, tutumları ve motivasyonlarına etkisi incelenmiştir. İlgili alanyazın incelendiğinde nicel çalışmalar ağırlıkta olmakla birlikte Türkçe öğretiminde eğitsel oyun kullanımının genel görünümü ortaya koyan bir meta-analiz, meta-tematik analiz, içerik analizi ya da sistematik alanyazın taraması çalışmasına rastlanmamıştır.

$\mathrm{Bu}$ araştırmanın amacı söz konusu araştırma sahasındaki boşluğa nitel ve tematik açıdan yaklaşarak yorumlayııı bir bakış açısı getirmeyi amaçlamaktadır. Ayrıca araştırma ile öğretim sürecinin önemli paydaşları ve araştırmacılar için eğitsel oyun tekniğinin etkililiğine ilişkin detaylı bir kaynak oluşturulması hedeflenmektedir. Belirtilen amaç doğrultusunda çalışmada yanıt aranan soru ise Türkçe öğretiminde eğitsel oyun kullanımının etkisinin belirlenmesidir.

Gerçekleştirilen bu araştırma ile Türkçe öğretiminde eğitsel oyun kullanımına yönelik gerçekleştirilen ve nitel veriye sahip olan çalışmaların bütünsel bir bakış açısıyla değerlendirilmesine ve yöntemin öğretim sürecindeki paydaşların ham verilerinin de ele alınmasına odaklanılmıştır. Bu noktada araştırmanın alanyazında yer alan nitel çalışmaların bütüncül bir bakış açısıyla sunulması bakımından kendine önemli bir yer edineceği düşünülmektedir.

\section{Araştırmanın Modeli}

\section{Yöntem}

Bu araştırmada eğitsel oyun kullanımın Türkçe öğretimine etkisi belirlenmeye çalışılmıştır. Bu doğrultuda Türkçe öğretiminde eğitsel oyun kullanımına yönelik gerçekleştirilen nitel çalışmaların meta-tematik analizi yapılmıştır. Meta-tematik analiz gerçekleştirilen nitel araştırmaların birincil çalışma verilerini inceleyen temaları veya konuları tanımlar, bu temaları analiz eder ve sistematik derlemelerden sonuçlar çıkarır. Bu yöntem uygulamaların gerekliliği, uygunluğu, kabul edilebilirliği ve etkililiği hakkında sonuçları sunmayı sağlamaktadır. Meta-tematik analiz ile konu hakkında yapılan analizler sonunda elde edilmiş tema ve kodların yeniden değerlendirmeye tabi tutularak ve araştırmacının kendi perspektifinden geçirilerek tekrar yorumlanması ve yeniden anlamlandırılması anlayışı vardır. Meta-tematik analizi meta-sentez analiz türlerinden ayıran en temel özellik ise analiz sürecine dahil edilen çalışmaların ham verilerinin de analiz edilerek temalaştırılmasıdır (Batdı, 2019). Meta-tematik analiz ile aynı konunun farklı boyutlarını ele alan çalışmaların ortak ve benzer yönlerinin nitel olarak sentezlenmesi ve örneklendirilmesi bütün çalışmalara ulaşma imkânı olmayan araştırmacılara, öğretmenlere ve karar alıcılara zengin bir başvuru kaynağı oluşturur (Ültay ve Çalık, 2012; Ünal, vd., 2006)

\section{Verilerin Toplanması ve Analize Dâhil Edilen Çalışmalar}

Araştırmada Türkçe öğretimi/eğitiminde eğitsel oyun kullanımı konusunda gerçekleştirilmiş çalışmalar analize dâhil edilmiştir. Google Scholar, Yükseköğretim Kurulu Tez Merkezi, Ulakbim TR Dizin, Web of Science, Eric ve Proquest veri tabanlarından yapılan taramalar ile çalışmalara ulaşılmıştır. Bu amaçla "eğitsel oyun", "Türkçe öğretimi", "educational game" ve "Turkish education" anahtar sözcükleri ile tarama gerçekleştirilmiştir. Tarama sonrasında ulaşılan çalışmalar için meta-tematik analize dâhil edilme ve hariç tutulma kriterleri belirlenmiştir. Bu doğrultuda çalışmanın analize dâhil edilme kriterleri; Türkçe öğretiminde eğitsel oyun kullanımı konulu çalışmalar olması, çalışmalarda nitel temaların ya da nitel ham verilerin bulunması, çalışmaların tam metinden oluşması dikkate alınmıştır. Çalışmaların hariç tutulma kriterleri ise; nitel veri bulunmaması, derinlemesine veri sağlamaması, amaca uygun olmaması ve tam metin olmamasıdır. Tarama sonrası ulaşılan çalışmalar analize dâhil edilme ve hariç tutulma kriterlerine göre incelenmiştir. Bu doğrultuda çalışma sistematik derlemeler 
ve meta-analizler oluşturulurken kullanılan kanıta dayalı kriterlere dayanan PRISMA karar kriterlerine (Liberati vd.,2009) uygun olarak yürütülmüştür ve tarama akışı diyagramı Şekil 1'de sunulmuştur.

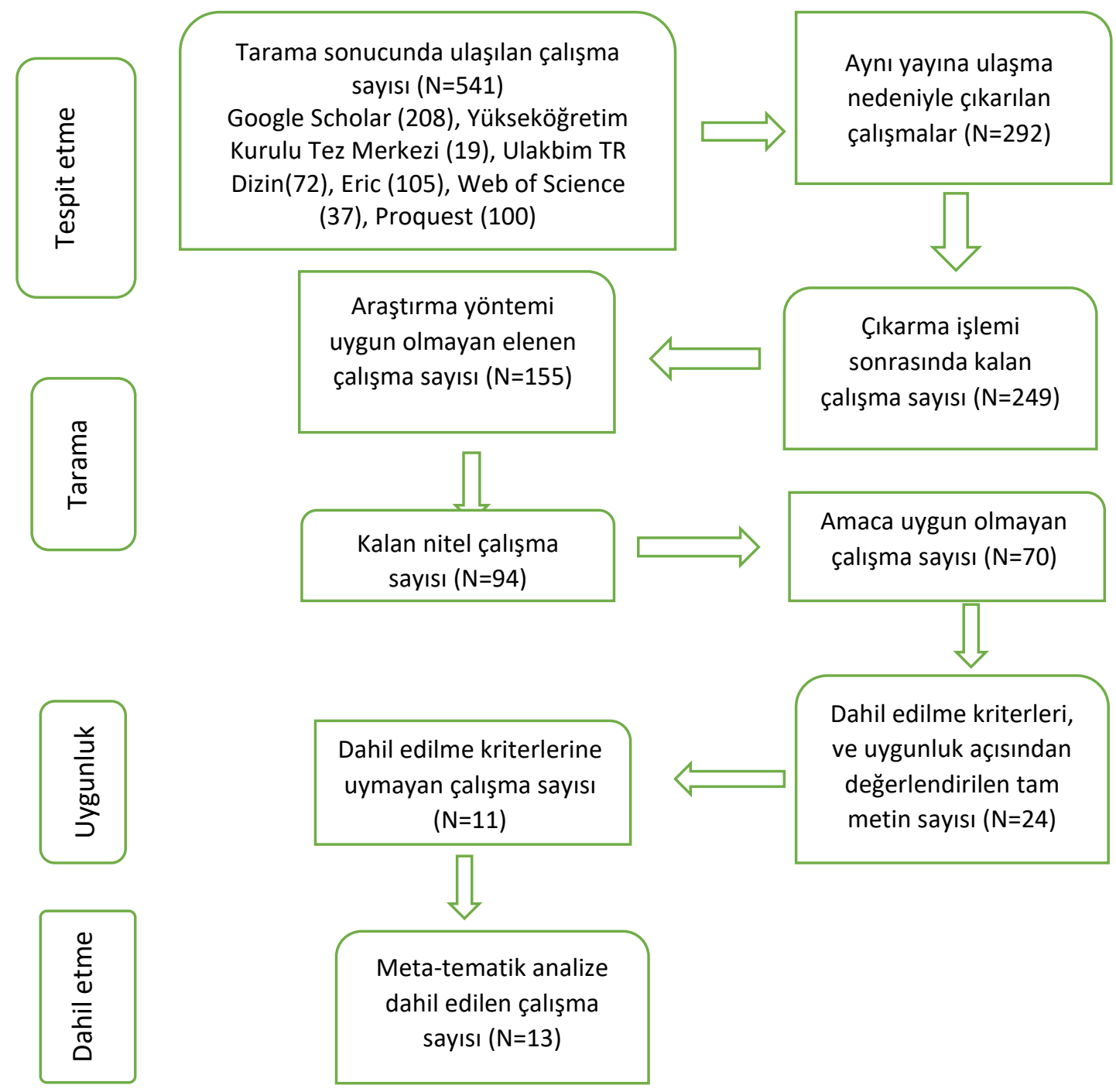

Şekil 1. Meta-Tematik Analize Dâhil Edilen Çalışmaların Akış Diyagramı

PRISMA'da görüldüğü üzere taranan veri tabanlarından ilk aşamada erişilen çalışma sayısı 541'dir. Erişilerek kaydedilen çalışmaların çalışmaya uygunluğunun tespitinde ilk olarak aynı yayına farklı veri tabanlarında rastlanılması nedeniyle birden fazla kaydedilen 292 çalışma araştırma sürecinden çıkarılmıştır. Geriye kalan 249 çalışma ise araştırma yöntemi bağlamında incelenmiştir. Bu bağlamda nitel araştırma yöntemi ile gerçekleştirilmeyen ya da herhangi bir nitel veri bulunmayan 155 çalışma analiz dışında tutulmuştur. Geriye kalan 94 çalışma ise araştırma amacına uygunluk bağlamında incelendiğinde 70 çalışma daha araştırma kapsamından çıkarılmıştır. Analiz sürecine uygunluk aşamasında ise kalan 24 çalışma dâhil edilme kriterleri ve uygunluk açısından değerlendirilmiştir. Bu aşamada ise dâhil edilme kriterlerine uymayan 11 çalışma araştırma kapsamı dışına alınmış sonuç olarak 13 çalışma meta-tematik analize dâhil edilmiştir. Tablo 1'de analiz sürecine dâhil edilen çalışmalar ile ilgili özet bilgiler sunulmuştur. Analiz sürecinde yer alan ham verilere veri yoğunluğu nedeniyle Tablo1'de yer verilememiştir. 
Tablo 1.

Analiz Sürecinde Yer Alan Çalışmaların Özet Bilgileri

\begin{tabular}{llll}
\hline Kod & Yazar /Yıl & Çalışma grubu & Veri kaynağı \\
\hline \multirow{3}{*}{ M1 } & Korucu ve & Türkçe & Görüşme
\end{tabular}

M1 Kurtlu (2016) öğretmenleri

(2)

Eğitsel açıdan oyun ve oyuncak kullanımının etkililiği / Türkçe eğitimine en uygun oyun ve oyuncaklar/ Türkçe derslerinde oyun ve oyuncak kullanımının dezavantajları/ Ders verilen ortamların uygunluğu/ Derslerde oyun kullanımına ilişkin yeterliklere sahip olma/Etkili olduğunu düşünme/Eğitsel açıdan etkili olduğunu düşünmeme/Yöntem ve teknik olarak kullanılabileceği/Yöntem olarak daha önce hiç denememe/Derslerde yöntem ve teknik olarak kullanımının zor olması/Materyale göre değişebilme/Her alana etki etme/iç̧eriğe göre oyun seçiminin değişeceği/Hayal dünyasını geliştiren oyunlar/Odaktan uzaklaşılması/Dezavantajının olmaması/Programın yetişmesini engellemesi/Rekabet oluşturması/Uygulama problemi/Derse uyumu zorlaştırması/Sınıfların kalabalık olması/Sınıfların fiziki şartlarının uygun olmayışı/Öğrenci düzeyi ve aile yapısının uygun olmayışı/Sınıf mevcudunun kalabalık olmaması/Sınıfın fiziki şartlarının uygunluğu/Öğrenci düzeyine inebilme/Özgün örnekler üretebilme/Çok etkili kullanamama/Öğretmenlik alan bilgisine sahip olma/Oyun ve oyuncak kullanımını bir plana göre gerçekleştirme/Türkçe öğretmenliği bölümünde materyal dersini hem teorik hem de uygulamalı olarak alma/Türkçe öğretmenliği bölümünde materyal dersini yüzeysel ve teorik olarak alma/Türkçe derslerinde oyun ve oyuncakları yeterli düzeyde kullanamama/Oyun ve oyuncak kullanımı ile ilgili gerekli bilgi ve beceriye sahip olmama/Öğretmenin yaşının ileri olması/Düz anlatım yönteminin daha kolay gelmesi Gültekin

(2019)

M3 Ertem (2016) Sinı

öğretmenleri
Görüşme ve Yararlılık ve verimlilik/ Eğlence ve mutluluk/ Dikkati toplama/ Kendine güven ve Gözlem sosyalleşme/ Derse aktif katılım/ Diğer derslerle ilişkilendirmeler/ Disiplini sağlama/ Öneriler

Görüşme

Sınıf öğretmenlerinin Türkçe dersinde oyun temelli dijital ortamları kullanma durumları ve bakış açıları/ Dijital ortamların avantajları/ Dijital ortamların Türkçe dersinde dezavantajları/ Türkçe dijital ortamların niteliği, yeterliği ve sahip olması gereken özellikler 


\begin{tabular}{|c|c|c|c|c|}
\hline M4 & $\begin{array}{l}\text { Öztemiz ve } \\
\text { Önal (2013) }\end{array}$ & $\begin{array}{l}\text { Sınıf } \\
\text { öğretmenleri }\end{array}$ & Görüşme & $\begin{array}{l}\text { Eğitimde Oyunun Yeri/Kullanılan Oyun Çeşitleri/Oyunların Öğrenme Üzerindeki } \\
\text { Etkileri/Oyun Tekniği ile Okuma Alışkanlığı Kazandırma/Okuma Alışkanlığı Kazandırmada } \\
\text { Etkili Oyunlar/Eğlenerek eğitme aracı/Eğitimin olmazsa olmazı/Öğretmenin } \\
\text { yardımcısı/Öğrenmenin temeli/Öğrenmeyi kalıı, hızlı ve keyifli bir hale dönüştürmesi }\end{array}$ \\
\hline M5 & Alevli (2020) & $\begin{array}{l}\text { 4. sınıf } \\
\text { öğrencileri }\end{array}$ & Görüşme & Çalışmada tema ya da alt temaya rastlanmamıştır. \\
\hline $\mathrm{T} 1$ & Kaya (2018) & $\begin{array}{l}\text { 4. sınıf } \\
\text { öğrencileri, } \\
\text { sınıf } \\
\text { öğretmenleri } \\
\text { ve velileri }\end{array}$ & $\begin{array}{l}\text { Görüşme ve } \\
\text { gözlem }\end{array}$ & $\begin{array}{l}\text { Bilişsel, Duyuşsal, Devinişsel beceriler/Zorluklar/Grup çalışması/Aile/ Öğretme öğrenme } \\
\text { süreci/Etkililik/ikna/Inanç/Derse karşı tutum/Ders hazırlıklı gelme/Sınıf içi ve sınıf dışı } \\
\text { öğrenme ortamı/Uygulama imkânı/Farklı derslerde kullanım/Akademik başarı/Öğrenme/Dil } \\
\text { becerileri/Özgüven/Sorunlu ve dezavantajlı öğrenciler/Eğitsel sorunlarda azalma/Akıll } \\
\text { yürütme/Düşünme/Yaratıcılık/Hayal gücü/Gönüllü katılım/Araştırma isteği/Merak/Derse ve } \\
\text { okula duygusal bağ/Anlama/Kendini ifade etme/Yorum yapma/Sorgulama }\end{array}$ \\
\hline $\mathrm{T} 2$ & $\begin{array}{l}\text { Al-Khudhur } \\
\text { (2016) }\end{array}$ & $\begin{array}{l}\text { Lisans } \\
\text { öğrencileri }\end{array}$ & Gözlem & Çalışmada tema ya da alt temaya rastlanmamıştır. \\
\hline T3 & Kara (2018) & $\begin{array}{l}\text { 6. sınıf } \\
\text { öğrencileri }\end{array}$ & Görüşme & Kelime safarisi oyunu ve oyun araçları/Türkçe derslerinde rahatsızık veren olay ve araçlar \\
\hline T4 & Erol (2019) & $\begin{array}{l}8-12 \text { yaş } \\
\text { öğrencileri }\end{array}$ & Görüşme & $\begin{array}{l}\text { Öğrencilerin eğitsel oyunlar ile ilgili duygu ve düşünceleri/Mutlu } \\
\text { edici/Güdüleyici/Eğlendirici/Sosyalleştirici/Öğrenimi destekleyici/Öğrenme ortamına çekici } \\
\text { ve yaratıcılığı geliştirici }\end{array}$ \\
\hline T5 & Sevim (2019) & $\begin{array}{l}\text { 5. sınıf } \\
\text { öğrencileri }\end{array}$ & Görüşme & 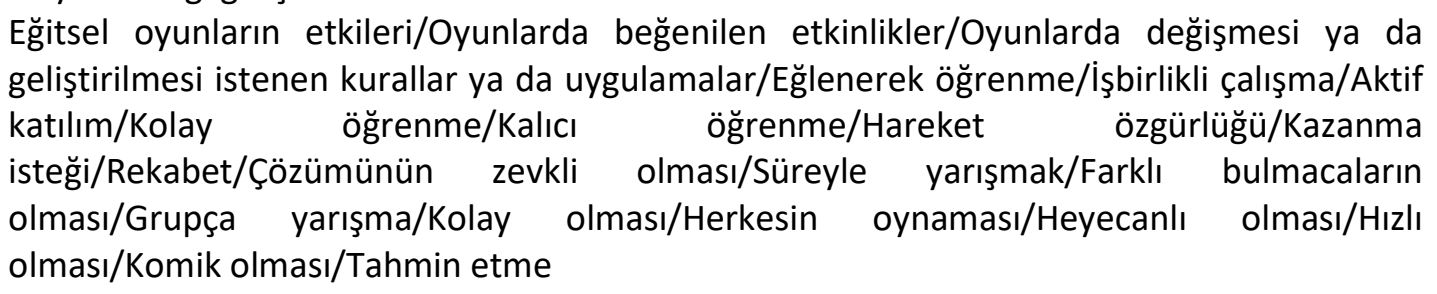 \\
\hline T6 & Şahin (2019) & $\begin{array}{l}\text { 6. sınıf } \\
\text { öğrencileri }\end{array}$ & Görüşme & $\begin{array}{l}\text { Türkçe dersinde kullanılabilirlik/Derse olan ilginin arttırmasına etkisi/ Kazanımları } \\
\text { pekiştirmeye etkisi }\end{array}$ \\
\hline $\mathrm{T7}$ & Ayık (2019) & $\begin{array}{l}\text { Türkçe } \\
\text { öğretmenleri }\end{array}$ & Görüşme & $\begin{array}{l}\text { Yazma becerisinin kazandırımasında oyun kullanımı/Erken yaşta yabancı dil olarak Türkçe } \\
\text { öğretimi alanında oyun kullanımı/Derslerde oyunla öğretimin etkisi/Oyunların yazma } \\
\text { becerilerine etkisi/Sonraki derslerde oyunlardan yararlanma düşüncesi }\end{array}$ \\
\hline
\end{tabular}


Tablo 1'de analiz sürecine dahil edilen çalışmaların veri kaynaklarının görüşme ve gözleme dayalı olduğu, çalışma gruplarının farklı yaş ve öğretim kademelerinden öğrencilerden oluştuğu, branş bazında ise sınıf ve Türkçe öğretmenlerini kapsadığı, kimi araştırmalarda araştırmacı gözlem bulgularının ham veri olarak verildiği ve yalnızca bir çalışmada veli görüşünün alındığı görülmektedir. Analize dâhil edilen iki çalışmada ise herhangi bir tema, alt tema ve kodlama yapılmamasına rağmen yapılan görüşmelere yönelik ham verilerin çalışmada sunulması söz konusudur. Bu doğrultuda söz konusu iki çalışmanın yalnızca ham verileri analiz edilmiştir. Ayrıca kimi çalışmalarda tema/alt tema ve kodlar yer almasına rağmen söz konusu temaları destekleyici katılımcı görüşleri ya da ham verilere yer verilmediği görülmüştür. Bu nedenle de söz konusu çalışmaları gerçekleştiren araştırmacılara ulaşılarak ham verilerin analiz sürecine dâhil edilebilmesi için ham verilerin paylaşılması talebinde bulunulmuştur.

\section{Kodlama Süreci}

Analiz sürecine dâhil edilen çalışmaların ham verileri (görüş, gözlem vb.) ile ana tema, alt tema, kod ve kavramlar detaylı biçimde incelenmiştir. Ardından araştırmanın amacına uygun olan kısımlar ayrılarak her bir çalışma bilgisayar ortamına aktarılmıştır. İzleyen süreçte çalışmalar, araştırma problemlerine göre tekrar incelenmiş ve her bir çalışmanın verileri için üst temalar oluşturulmuştur. Incelenen her bir çalışma, çalışmanın türü ile de ilişkili olacak biçimde $M 1, M 2, \ldots$ (M: Makale), T1, T2,... (T: Tez) şeklinde kodlanmış ve araştırmada bu kodlar kullanılmıştır.

\section{Verilerin Analizi}

Araştırmada Türkçe öğretimi/eğitimi alanında eğitsel oyun kullanımına yönelik gerçekleştirilmiş nitel çalışmalarda sunulan tema, alt tema, kavram, kod ve ham verilerin (katılımcı görüşü, gözlem vb. yollarla elde edilmiş ham veri) içerik analizi yoluyla analizi gerçekleştirilerek tema üstü temalar ve alt temalar yeniden oluşturulmuştur. Bunun için kodlama süreci sonrası her bir çalışma için oluşturulan temaların birbirleriyle ilişkisini belirlemede tema, alt tema ve kavramlar bir araya getirilerek listelenmiştir. Öne çıkan temaların listelenip karşılaştııılmasıyla çalışmaların hangi yönlerden benzer olduklarının belirlenmeye çalışılmıştır. Oluşturulan tema ve alt temalar şekiller dahilinde sunulmuş ve yorumlanmıştır. Şekillerin sunumunda çevrim içi bir kavram ağı oluşturma sitesinden yararlanılmıştır. Elde edilen tema ve alt temaları destekleyici nitelikte olan doğrudan alıntılarda ilgili bölümlerde sunulmuştur. Analiz sonucunda ortaya çıkan temaların uygunluğu bir alan uzmanı tarafından değerlendirilerek temaların uygunluk düzeyinin denetimi sağlanmıştır.

\section{Geçerlik ve Güvenirlik}

Araştırmada geçerliliğin sağlanmasında öncelikle araştırma sürecinin her aşamasının detaylandırılarak açıklayıcı ve tanıtıcı biçimlerde paylaşılmasına özen gösterilmiştir. Alanyazın taramalarında sıklıkla düşünülen araştırmacı önyargısı sorununun üstesinden gelebilmek adına geniş veri tabanları taranmış ve kapsamlı bir tarama çalışması gerçekleştirilmiştir. Ayrıca araştırmada Maxwell'in (1992) nitel araştırmalarda geçerlilik için önerdiği ölçütlerinin Batdı (2019) tarafından metatematik analiz çalışmalarına uyarlamış olduğu kriterler dikkate alınmıştır. Bu doğrultuda çalışmada taramalar sırasında konu ile ilgili ulaşılabilen tüm yayınlar detaylı bir biçimde incelenebilmek amacıyla dosyalara kaydedilmiştir. Elde edilen veriler en açık ve doğru biçimde betimlenerek betimsel geçerlik sağlanmaya çalışımıştır.

Kuramsal geçerliğin sağlanmasında araştırmacı tarafından belirlenen tema, kategori ve yorumların sosyal gerçeklik ile uyumlu olmasına dikkat edilmiş ve oluşturulan kavram ve kategorilerin araştırma sonuçlarıyla örtüşür ve birbirini tamamlar nitelikte olması sağlanmıştır. Ayrıca kavramların anlamlı bir bütünlük oluşturması ve bulguların önceden belirlenen kavramsal çerçeveye uyum sağlaması çalışmanın iç geçerliğini destekler niteliktedir. Araştırmanın yorumlayıcı geçerliliğinin sağlanmasında ulaşılan çalışmalardaki birincil verilerin yorumlanmasında katıımcının bakış açısının korunarak yorumlanmasına çalışılmıştır. Bu doğrultuda katılımcı görüşlerinin yorumlanmasını izleyen süreçte söz konusu yorumları destekleyici doğrudan alıntılara yer verilmiştir. 
Araştırma güvenirliğinin sağlanmasında Lincoln ve Guba'nın (1985) nitel çalışmalar için önerdiği aktarılabilirlik, güvenilebilirlik ve teyit edilebilirlik ölçütleri dikkate alınmıştır. Bu doğrultuda aktarılabilirliği kanıtlamak için örneklem seçiminin nasıl yapıldığı, örneklemde yer alan çalışmaların özellikleri ve örneklemdeki araştırmaların künyeleri açıkça belirtilmiştir. Güvenilebilirliğin sağlanmasında analize dâhil edilen çalışmaların kayıt altında tutulması ve çalışma kaynaklarının sunulması gerçekleştirilmiştir. Çalışmada teyit edilebilirlik ölçütü ise çalışma kapsamına alınan araştırmaların ham verilerinin kullanımı ile karşılanmaya çalışıımışır. Söz konusu geçerlik ve güvenirlik çalışmaları sonucunda araştırmanın gelecekte yapılacak çalışmalara geçerli ve güvenilir düzeyde yarar sağlayacağı düşünülmektedir.

\section{Araştırma ve Yayın Etiği}

Bu çalışmada "Yükseköğretim Kurumları Bilimsel Araştırma ve Yayın Etiği Yönergesi" kapsamında uyulması belirtilen tüm kurallara uyulmuştur. Yönergenin ikinci bölümü olan "Bilimsel Araştırma ve Yayın Etiğine Aykırı Eylemler" başlığı altında belirtilen eylemlerden hiçbiri gerçekleştirilmemiştir.

\section{Bulgular}

Bu çalışmada meta-tematik analiz bağlamında elde edilen veriler "Türkçe dersinde eğitsel oyun tekniğinin kullanımı", "eğitsel oyun tekniğinin öğretmen yeterliklerine etkisi, "öğrenci kazanımlarına etkisi" ve "öğretme-öğrenme sürecine etkisi" olarak temalaşmıştır. Söz konusu temalar ve alt temalar bulgular bölümünün alt başlıkları biçiminde sunulmuştur.

\section{Türkçe Dersinde Eğitsel Oyun Tekniğinin Kullanımı}

Türkçe dersinde eğitsel oyun tekniğinin kullanımı ana temasına ilişkin alt temalar Şekil 2'de görülmektedir.

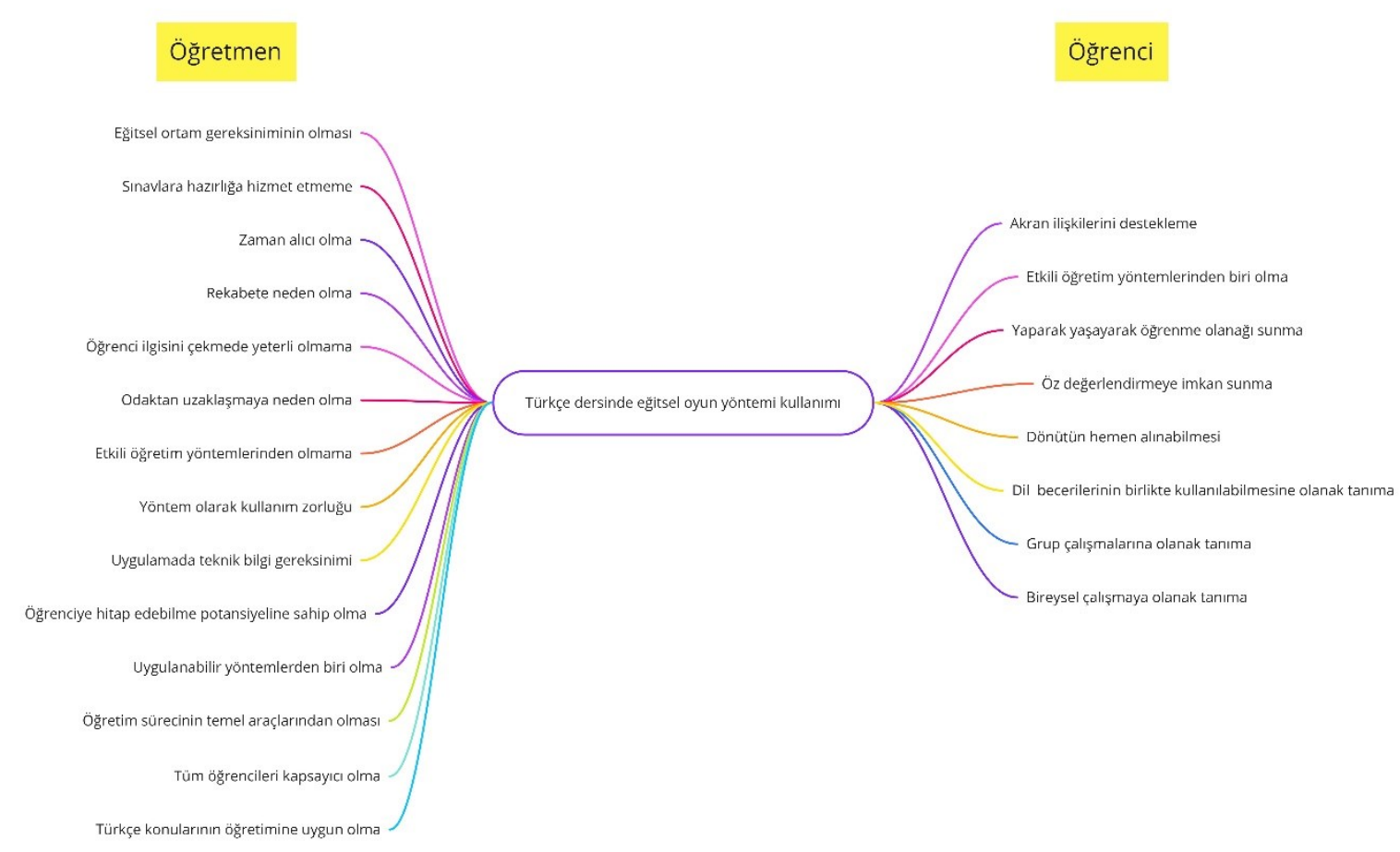

Şekil 2. Türkçe Dersinde Eğitsel Oyun Tekniğinin Kullanımı 
Şekil 2'de Türkçe dersinde eğitsel oyun tekniğinin kullanımına ilişkin olarak ortaya çıkan alt temalar öğretmen boyutunda ve öğrenci boyutunda sunulmuştur. Öğretmen boyutunda eğitsel oyun tekniğinin Türkçe dersinde kullanımına yönelik olumlu ve olumsuz anlamlar taşıyan alt temalar yer alırken öğrenci boyutunda olumsuz anlam taşıyan herhangi bir alt tema görülmemektedir. Öğretmen boyutunda eğitsel oyun tekniğinin etkili bir yöntem olarak görülmemesi, sınavlara hazırlığa hizmet etmemesi, yöntem olarak kullanımının zorluğu ve eğitsel ortam gereklilikleri gibi olumsuz alt temaların yanı sıra uygulanabilir, öğrenciye hitap etme potansiyeline sahip, bireysel ve grup çalışmalarına olanak sunma ve tüm öğrencileri kapsayıcı olma gibi olumlu alt temalarında ortaya çıktığı görülmektedir. Öğrenci boyutunda ise özellikle olumsuz anlam taşıyan bir temaya rastlanmaması ve yöntemin olumlu özelliklerinin ön plana çıkması Türkçe dersinde eğitsel oyun kullanımının olumlu etkilerini göstermektedir. Türkçe dersinde eğitsel oyun kullanımı temasına ilişkin referans alınan çalışmalardan bazıları şunlardır:

M1 kodlu çalışma "Sınavlara yönelik konu anlatıyorum.", "Derslerde farklı faaliyetlerde öğrencilerde gevşeme oluyor ve dersi kaynatma başlıyor. Verimli olmuyor." (s.548)

M3 kodlu çalışma "Ne yazık ki Türkçe dersindeki eğitsel oyunlar diğer ticari oyunlar kadar eğlenceli değil bu nedenle öğrencilerimin ilgisini yeterince çekmiyor..."(s.7)

M4 kodlu çalışma "Oyun eğitimin temelidir. Çocuğa önce oyun oynamayı öğretirseniz gerek okumayı gerekse diğer eğitsel süreçleri anlaması çok daha kolay olur. Oyun benim eğitimde kullandığım en temel araçtır.... İzleyen süreçte oyunla yaklaştığınız bu çocuklara gerek okuma yazma gerekse diğer dersler çok daha kolay ve anlaşılır hale gelmektedir." (s.72)

T5 kodlu çalışma "...yalnız başımıza da oynamadık. Öğretmen hep gruplar kurdu. Grup içinde arkadaşlarımızla çok iyi çalıştık." (s.94)

\section{Eğitsel Oyunların Öğretmenlik Yeterliklerine Etkisi}

Türkçe dersinde eğitsel oyun kullanımının öğretmen yeterliklerine etkisi temasının altında yer alan alt temalar Şekil 3'te görülmektedir.

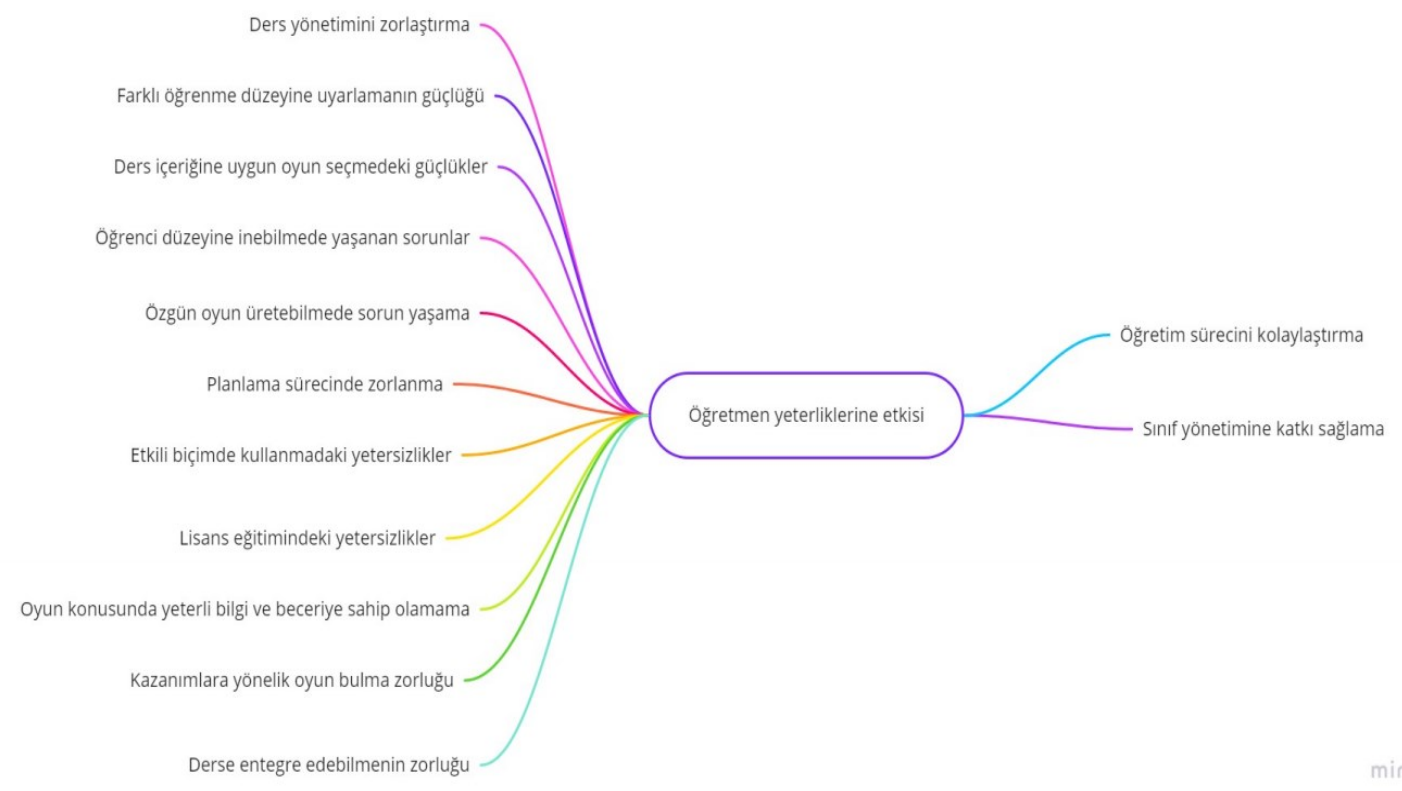

Şekil 3. Eğitsel Oyunların Öğretmen Yeterliklerine Etkisi

Şekil 3'te öğretmen boyutundan oluşturulan söz konusu alt temalardan bazılarının öğretim sürecini kolaylaştırma ve sınıf yönetimine katkı sağlama gibi öğretmen yeterliklerini destekleyici anlam ifade ettiği görülmektedir. Bunun yanı sıra diğer alt temaların ise olumsuz anlam taşıdığı görülmektedir. 
Söz konusu bulguya ilişkin referans alınan ifadelerden bazıları M1 kodlu çalışma "Yaşımdan dolayı çocukların seviyesine inmek zor oluyor." ve "Çünkü Türkçe dersi çok geniş bir alan ve az çok her şeye dair bilgi sahibi olmak gerekiyor." (s.552), M3 kodlu çalışma "Kazanımlara yönelik çoğunlukla oyun bulmak zor oluyor." (s.7) biçimindedir.

\section{Eğitsel Oyunların Öğrenci Kazanımlarına Etkisi}

Türkçe dersinde eğitsel oyun kullanımının öğretmen, öğrenci ve veli boyutundan öğrenci kazanımlarına etkisi incelenmiştir. Şekil 4'te eğitsel oyunların öğretmen ve öğrenci boyutundan öğrenci kazanımlarına etkisi Şekil 5'te ise eğitsel oyunların öğrenci kazanımlarına etkisine ilişkin öğretmen ve öğrenci ortak alt temaları yer almaktadır. Şekil 6 'da veli boyutundan eğitsel oyunların öğrenci kazanımlarına etkisi verilmiştir. Bu bölümde son olarak Şekil 7 ile öğretmen-öğrenci ve veli boyutundan eğitsel oyunların öğrenci kazanımlarına etkisine ilişkin ortak alt temalar sunulmuştur.

Şekil 4'te yer alan alt temalara ilişkin bulgular eğitsel oyunların öğrenci kazanımları bağlamında bilişsel ve duyuşsal boyutlarda katkılarının yanı sıra, dil becerilerinin gelişiminde de öğrencileri desteklediğini göstermektedir. Öğretmenlerin öğrencilere kıyasla eğitsel oyunların öğrenci kazanımlarına etkisine yönelik daha sınırlı sayıda tema ortaya çıkarması ise dikkat çekici bir bulgu olarak sunulmuştur. Söz konusu alt temalardan dil becerilerinin gelişimini desteklemeye ilişkin referans alınan ifadelerden bazıları şunlardır:

M5 kodlu çalışma "Kelimeleri, deyimleri ve atasözleri kullanarak dil becerilerimizi geliştirecek bir oyundur. Oyunda bilmediğimiz bir çok kelime ve deyim var ve bu oyun size bunları öğretiyor......" (s.151)

T1 kodlu çalışma ".....Sesimi güzel ayarladım mimik hareketlerine dikkat ettim arkadaşlarımın ilgisini çektim açık ve anlaşıı bir biçimde konuştum iyi hazırlandım materyalimi güzel kullandım......." (s.170)

T7 kodlu çalışma "Yazma hatalarını azaltması." (s.114)

T6 kodlu çalışma "Ses olaylarını bilmiyorum fakat oyunda son hecelerle ses olaylarını eşleştirip puan kazanabildim, bazı ses olaylarını bilmesem de bazılarına ait kelimeleri öğrendim ve bu oyunu sevdim." (s.61). 


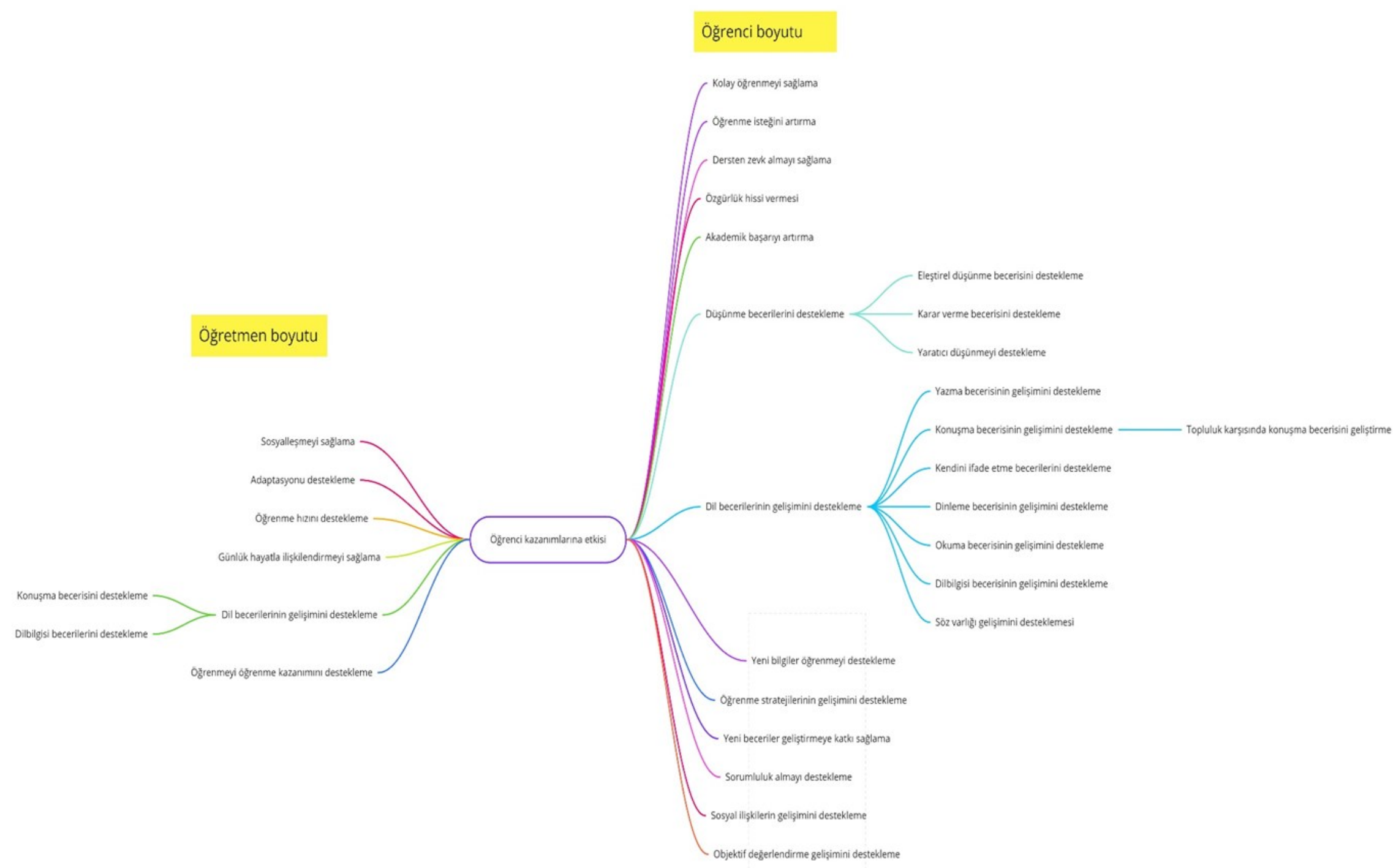

Şekil 4. Eğitsel Oyunların Öğrenci Kazanımlarına Etkisi 
Şekil 5'te ise eğitsel oyunların öğrenci kazanımlarına etkisine ilişkin öğretmen ve öğrenci ortak alt temaları sunulmuştur.

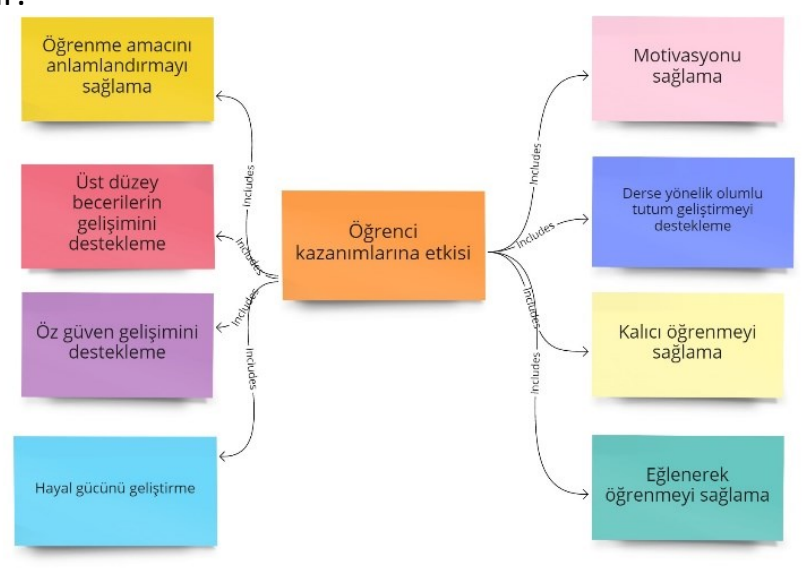

Şekil 5. Eğitsel Oyunların Öğrenci Kazanımlarına Etkisi Öğretmen ve Öğrenci Ortak Alt Temaları

Şekil 5'te eğitsel oyunların öğrenci kazanımlarına etkisine yönelik öğretmen ve öğrenci boyutunda ortaya çıkan ortak yapı Türkçe dersinde kullanılan eğitsel oyunların öğrenci kazanımlarını desteklemede uygun bir yöntem olduğunu göstermektedir. Referans alınan ifadelerden bazıları T1 kodlu çalışma "...Türkçede normalde sıkılırım ama hiç sıkılmıyorum." (s.106), T3 kodlu çalışma "Türkçe dersini artık çok seviyorum." (s.142), T5 kodlu çalışma "Bence etkili. Çünkü herkes bu oyunları oynamak istedi. Oyunu oynamak istemeyen yoktu...." (s.95), M2 kodlu çalışma "....çocukların hayal dünyasını, düşüncesini, hafızasını geliştirebilecek yöntem olarak görüyorum. Başarılarını artıracağını düşünüyorum." (s.473) şeklinde sunulabilir. Eğitsel oyunların veli boyutundan öğrenci kazanımlarına etkisi ise Şekil 6'da sunulmuştur.

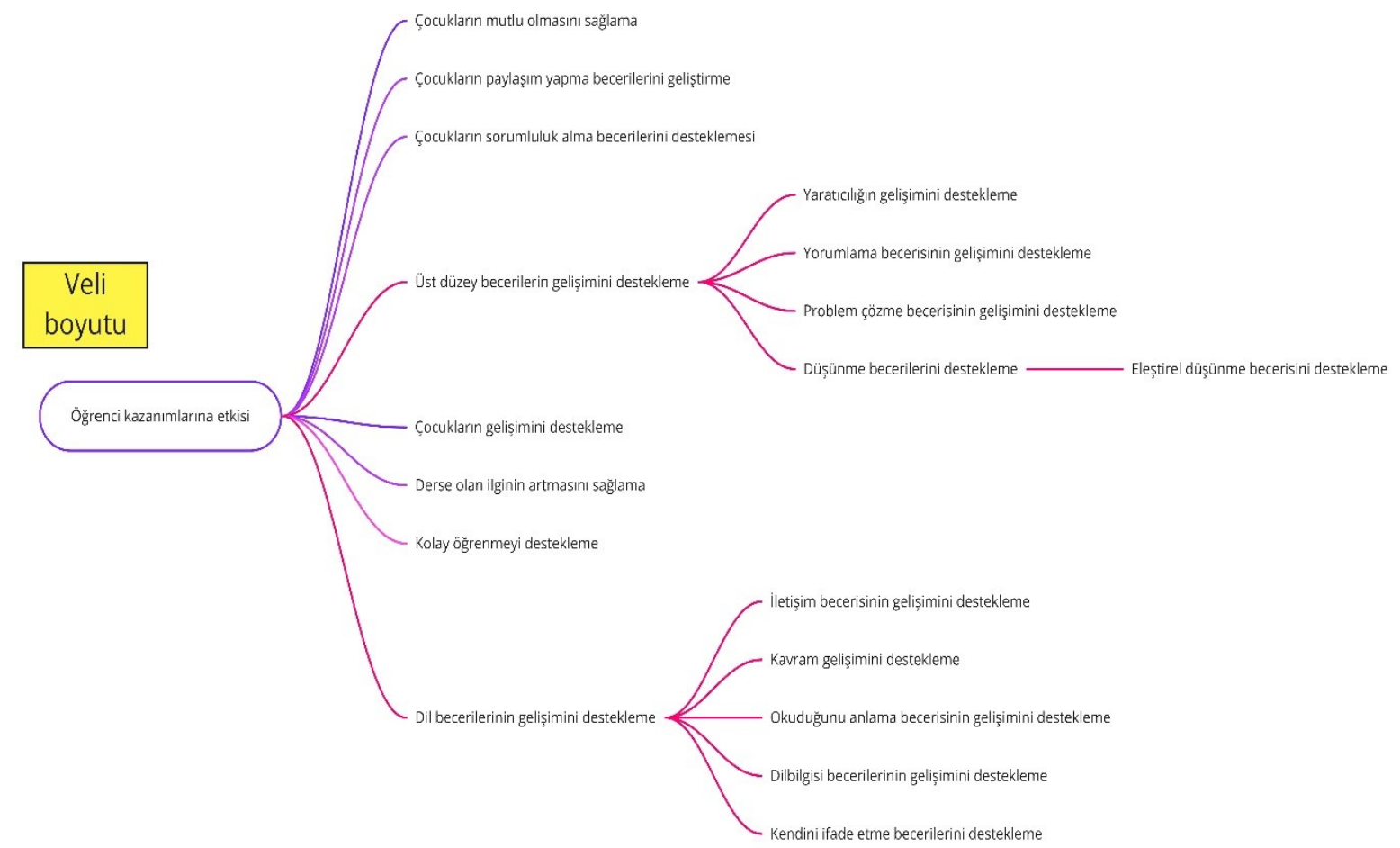

Şekil 6. Eğitsel Oyunların Öğrenci Kazanımlarına Etkisi Veli Boyutu

Şekil 6 incelendiğinde velilerin Türkçe dersinde eğitsel oyun kullanımı ile çocuklarının dil gelişimlerinin desteklendiği, Türkçe dersine olan ilgilerinin arttığı, daha kolay öğrendikleri, üst düzey 
becerilerinin desteklendiği ve duyuşsal boyutta olumlu kazanımlar edindiklerine yönelik temalar oluşturdukları görülmektedir. Bu doğrultuda veli, öğretmen ve öğrenci boyutundan eğitsel oyunların öğrenci kazanımlarına etkisinin ortak temaları Şekil 7' de verilmiştir.

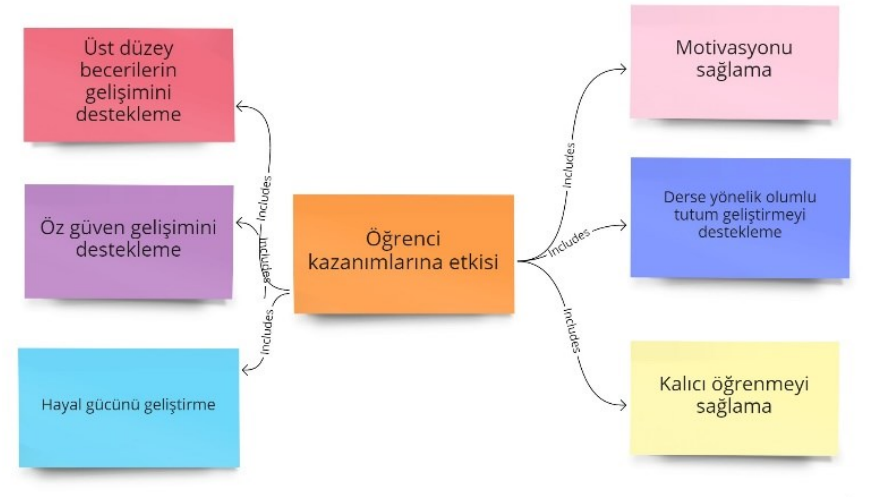

Şekil 7. Eğitsel Oyunların Öğrenci Kazanımlarına Etkisi Öğretmen-Öğrenci-Veli Ortak Temaları

Şekil 7'de görüldüğü üzere eğitsel oyunların öğrenci kazanımlarının etkisine yönelik öğretmenöğrenci ve velilerin; hayal gücünü destekleme, öz güveni destekleme, üst düzey becerilerin gelişimini destekleme, motivasyonu sağlama, derse yönelik olumlu tutum geliştirmeyi destekleme ve kalıcı öğrenmeyi sağlama gibi ortak alt temaları bulunmaktadır. Söz konusu alt temalardan biri olan motivasyonu sağlamaya yönelik referans alınan ifadelerden bazıları T1 kodlu çalışma "Ben çok eğlendim ve sürekli yapmak isterdim." (s.104), T1 kodlu çalışma "....Yaptığınız etkinlikleri çok seviyor. Derslerinize girmek için can atıyor...." (s.158), T3 kodlu çalışma "Oyunu çok beğendim. Oyunda ödülün olması beni çok motive etti, çok heyecanlandırdı." (s.142), M4 kodlu çalışma "Yarım bırakılan bir hikayeyi öğrencilerin tamamlamasını istiyorum....Boşlukları daha güzel tamamlama isteği çocuğu okumaya teşvik ediyor" (s.74) şeklindedir.

Bir diğer ortak alt tema olan kalıcı öğrenmeyi sağlamaya ilişkin referans alınan ifadelerden bazıları ise M2 kodlu çalışma “....onların eğlenerek öğrenmelerini sağlıyor. Bu da bilgilerin kalıcı olmasını sağlıyor...." (s.469), M3 kodlu çalışma "Türkçe dersini sevdirme, öğrencilerin öğrenmelerini daha kalıcı hale getirme, kavramları görselleştirme, eğlenerek öğrenme, öğrenilenleri pekiştirme, düşünme becerilerini geliştirme gibi faydaları var" (s.6), M4 kodlu çalışma "Oyun öğrencilerin konuyu daha çabuk kavramasına, daha dikkatli dinlemesine ve dolayısıyla daha kalıcı anlamasına neden olurken öğretmenin de işini kolaylaştırır......" (s.74), T1 kodlu çalışma "Oğlumla sizin sınıf içi ve eve verdiğiniz etkinliklerinizi değerlendirdiğimizde çok eğlenceli olduğunu, kalıcı ve etkili olduğunu ifade ediyor....." (s.154) biçimindedir.

\section{Eğitsel Oyunların Öğretme- Öğrenme Sürecine Etkisi}

Eğitsel oyunların öğretme-öğrenme sürecine etkisinin öğretmen ve öğrenci boyutundan yansımaları sonucu ortaya çıkan alt temalar Şekil 8.de eğitsel oyunların öğretme-öğrenme sürecine etkisinin öğretmen ve öğrenci boyutlarından ortaya çıkan ortak alt temaları ise Şekil 9 'da sunulmuştur. 


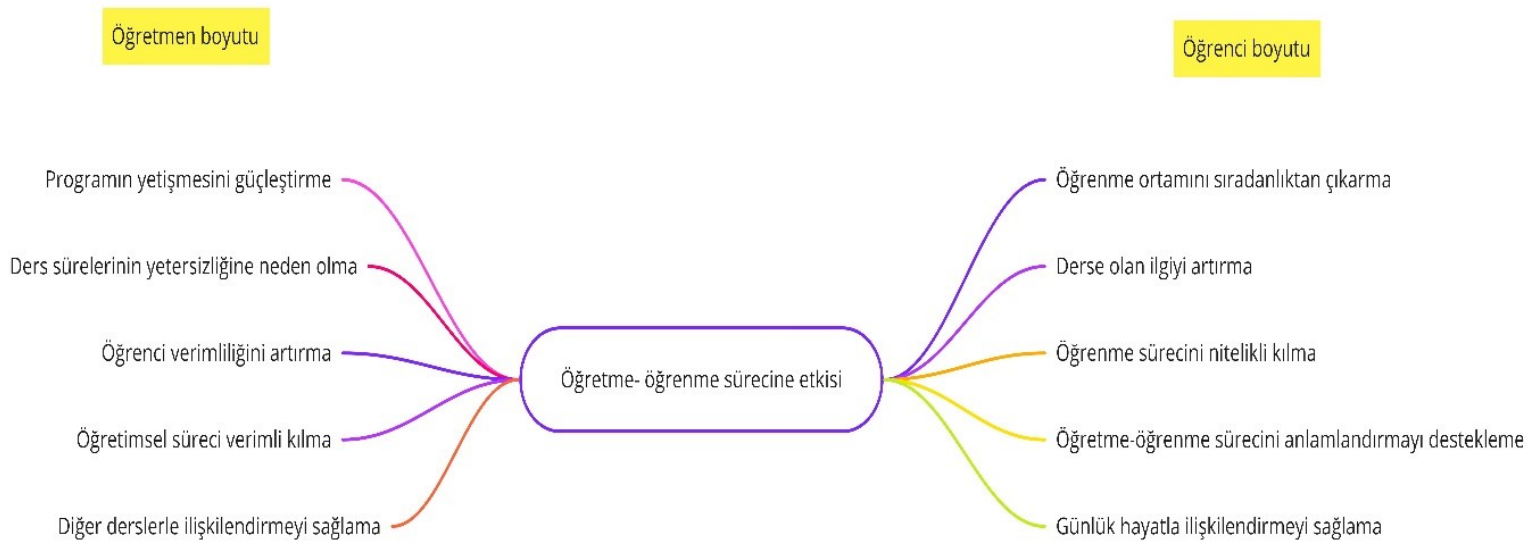

Şekil 8. Eğitsel Oyunların Öğretme-Öğrenme Sürecine Etkisi

Şekil 8 incelendiğinde Türkçe dersinde eğitsel oyun kullanımının öğretim sürecinde verimliliği, ilgiyi ve anlamlandırmayı arttırdığı aynı zamanda diğer derslerle ve günlük hayatla ilişkilendirmenin sağlanmasına ve öğrenme ortamının sıradanlıktan çıkarılmasına yardımcı olduğu görülmektedir. Öğretmen boyutunda ayrıca eğitsel oyun kullanımının öğretme-öğrenme sürecinde öğretim programının yetişmesini güçleştirdiği ve ders sürelerinin oyunlar nedeniyle yetersiz kaldığı gibi öğretim sürecinin olumsuz etkilendiğine yönelik alt temalar da bulunmaktadır. Söz konusu bulgu öğretmenlerin Türkçe dersinde eğitsel oyunları bir teknik olarak kullanmada zaman yönetimi konusunda daha planlı ve programlı olmaları gerektiğini göstermektedir. Söz konusu alt temalara ilişkin çalışmalardan alınan referanslardan bazıları M2 kodlu çalışma "......... Verimimizde gayet iyi, iyi verim alıyoruz. Gayet güzel, performansları güzel. Artarak devam ediyor." (s.467) şeklindedir. Eğitsel oyunların öğretme-öğrenme sürecine etkisinin öğretmen ve öğrenci boyutlarından ortaya çıkan ortak alt temalar ise Şekil 9'da sunulmuştur.

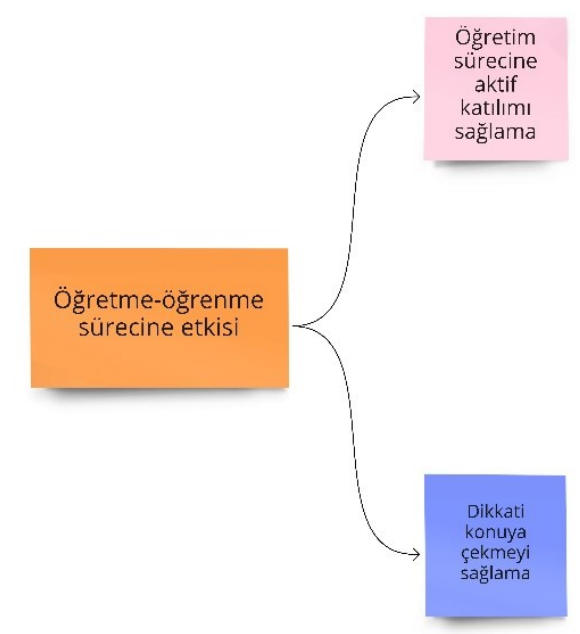

Şekil 9. Eğitsel Oyunların Öğretme Öğrenme Sürecine Etkisi Öğretmen ve Öğrenci Ortak Alt Temaları

Şekil 9 incelendiğinde ise öğretmen ve öğrencilerin Türkçe dersinde eğitsel oyun kullanımının öğretme-öğrenme sürecine etkisinin dikkat çekme basamağında etkilediği ve öğretim sürecine aktif katılımı sağladığı yönünde ortak alt temaları bulunmaktadır. Söz konusu bulguya ilişkin referans ifadelerden bazıları M2 kodlu çalışma "Şimdi oyunla öğretim uygulaması bazı fark ettiğim yönleri, 
gerçekten çocukların dikkatlerini toplaması açısından çok önemli..." (s.469), T7 kodlu çalışma "Öğrencilerin derslere katılımını artırması." (s.114) şeklindedir.

\section{Tartışma ve Sonuç}

Eğitsel oyun kullanımın Türkçe öğretimine etkisini meta-tematik analiz aracılığıyla belirlemeyi amaçlayan bu araştırmada araştırma sonuçları bulgular ışığında dört ana tema eşliğinde sunulmuştur. Araştırma sonuçlarının birinci ana temasını Türkçe dersinde eğitsel oyun tekniğinin kullanımı oluşturmaktadır. İkinci ana temayı eğitsel oyunların öğretmen yeterliklerine etkisi oluştururken üçüncü ana temada eğitsel oyunların öğrenci kazanımlarına etkisine yönelik sonuçlar yer almıştır. Son olarak eğitsel oyunların öğretme-öğrenme sürecine etkisi sonucuna yer verilmiştir.

Sonuçların ele alındığı ilk boyut olan Türkçe dersinde eğitsel oyun tekniğinin kullanımına yönelik öğretmen boyutunda eğitsel oyun tekniğinin etkili bir yöntem olarak görülmemesi, sınavlara hazırlığa hizmet etmemesi, yöntem olarak kullanımının zorluğu ve eğitsel ortam gereklilikleri gibi olumsuz anlam taşıyan alt temalar yer almaktadır. Söz konusu araştırma sonucu öğretmenlerin, eğitsel oyun tekniğine ilişkin farklı bakış açılarının yansımasının neden olduğu şeklinde yorumlanabileceği gibi teknik konusunda bilgi gereksinimlerinden de kaynaklanıyor olabilir. Nitekim UNICEF'in (2018) oyun yoluyla öğrenmeye ilişkin hazırlamış olduğu raporda öğretmenlerin oyun tabanlı öğretim yöntemleri ile ilgili bilgi gereksinimlerinin olduğu, akademik kavramların öğretiminde eğitsel oyunların yetersiz görüldüğü, öğretim programlarına oyunla öğretim yöntemlerinin entegre edilmemesi ve oyunla öğretim için sınıf ortamlarının eğitsel ortam eksikliklerine değinilmiştir. Eğitsel oyunların öğretimde kullanımına ilişkin olarak bu araştırmanın sonuçları da UNICEF'in raporunda vurguladığı sorunlara benzer şekilde ortaya çıkmıştır. Eğitsel oyun tekniğinin uygulanmasında dikkat edilmesi gereken noktalardan birinin eğitim ortamına uyarlanabilirlik olduğu düşünüldüğünde öğretmen yeterliklerinin yeniden değerlendirilmesi gündeme gelmektedir. Öğretmenlerin güncel öğretim yöntem teknikleri konusunda yeterliklerinin gözden geçirilerek öğretim programlarına söz konusu güncel öğretim yaklaşımlarının entegre edilmesi söz konusu olumsuz bakış açısının ortadan kalkmasına yardımcı olacaktır. Araştırma sonuçları aynı zamanda söz konusu olumsuz bakış açısının yanı sıra Türkçe dersinde eğitsel oyun tekniğinin kullanımına yönelik olumlu bakış açılarını da ortaya çıkarmıştır. Özellikle "uygulanabilir yöntemlerden biri olma" alt teması yukarıda öğretmen yeterliklerine ilişkin yapılan yorumu güçlendirmektedir.

Araştırmanın bir diğer sonucu ise öğretmenlerin söz konusu olumsuz bakış açılarına rağmen öğrenci boyutundaki tüm temaların olumlu anlamlar içermesidir. Öğrencilerin Türkçe dersinde eğitsel oyun tekniğinin kullanımına yönelik yöntemin olumlu özelliklerini ön plana çıkarmaları Türkçe dersinde eğitsel oyun kullanımının öğrenciler üzerindeki olumlu etkilerini göstermektedir. Nitekim eğitsel oyunlar sayesinde her katılımcıya eşit fırsatlar tanınması, öğrenme çıktılarının iyileştirilmesi, katılımcıların motive edilmesi, eğitimin daha eğlenceli hale dönüştürülmesi, akran etkileşiminin sağlanması, öğrenmenin hızlandırılması, önceden tasarlandığı için risk durumlarının azaltılması, temel öğrenme noktalarına vurgu yapılması, düşüncelerin detaylandırılması ve test edilmesi ile yapıcı geribildirimlerin alınması noktasında fırsatlar sunulmaktadır (Alkış Küçükaydın, 2020). Araştırma sonuçları da öğrencilerin eğitsel oyun tekniğinin söz konusu olumlu fırsatlarını deneyimlediklerini göstermektedir.

Sonuçların ele alındığı ikinci boyutta eğitsel oyunların öğretmen yeterliklerine etkisi incelendiğinde araştırmanın ilk boyutundaki sonuçların gerekçesinin sunulduğu söylenebilir. Analiz edilen çalışmalarda öğretmenlerin Türkçe dersinde eğitsel oyun kullanımındaki yeterliklerinden ziyade yöntem kullanımındaki yetersizlikleri ön plana çıkmaktadır. Öğretmenlerin Türkçe öğretiminde eğitsel oyunları planlamada ve derse hazırlıkta; farklı öğrenme düzeylerine uyarlamada, ders içerik ve kazanımlara yönelik oyun bulmada, özgün oyun üretebilme zorluk yaşadıkları ve eğitsel oyunları derse entegre edebilmede sorun yaşadıkları; öğretme- öğrenme sürecinde ise ders yönetiminde, öğrenci düzeyine inebilmede ve etkili biçimde süreci yürütebilmede yetersiz kaldıkları görülmektedir. Söz konusu araştırma sonucu Kırbaş ve Koparan Girgin (2018) ile Yılmaz, Kırımoğlu ve Yamanyurt'un (2019) araştırma sonuçlarıyla örtüşmektedir. Araştırma sonucu söz konusu yetersizliklerin nedenlerinden birinin hizmet öncesi öğretmen eğitimindeki eksikliklerden kaynaklandığını göstermektedir. Nitekim 
alanyazında da öğretim sürecinde eğitsel oyun kullanımında öğretmen yeterliklerine yönelik gerçekleştirilen araştırmalar belli bir mesleki hizmet yılının üstündeki öğretmenlerin lisans eğitimlerinde eğitsel oyun tekniğinin kullanımına ilişkin bir eğitim almadıklarını göstermektedir (Hazar ve Altun, 2018). Analiz edilen çalışmalarda da öğretmenlerin eğitsel oyun ve oyun tabanlı öğretime ilişkin lisans düzeyinde eğitim almamalarının bu yetersizliklere neden olduğu sonuçları bulunmaktadır. Bunun yanı sıra alanyazında öğretmen adaylarıyla gerçekleştirilen çalışmalarda öğretmen adaylarının da konu alanlarında eğitsel oyun bulmada, tasarlamada ve uygulamada zorluk yaşadıkları görülmektedir (Akcanca ve Sömen, 2018; Kapucu Seçkin ve Çağlak, 2018; Önen, Demir ve Şahin, 2012). Alanyazın ve araştırma sonuçları birlikte değerlendirildiğinde hizmet öncesi ve hizmet içi öğretmen eğitiminde özel öğretim yöntemlerine ilişkin verilen eğitimlerin gözden geçirilerek güncel yaklaşımlar doğrultusunda programların yeniden şekillendirilmesi önemli görülmektedir.

Araştırmanın üçüncü boyutuna ilişkin sonuçlar Türkçe dersinde eğitsel oyun kullanımının öğrenci kazanımlarını olumlu yönde etkilediğini göstermektedir. Bu doğrultuda analiz edilen çalışmalarda öğretmen, öğrenci ve velilerin eğitsel oyunların öğrencilerin bilişsel, duyuşsal ve sosyal boyutlarda desteklendiği görülmektedir. Veli boyutundaki araştırma sonuçları velilerin gözlemlerine dayanmakla birlikte öğretmen ve öğrenci boyutunda da benzer alt temalar bulunması eğitsel oyunların öğrenci kazanımlarını farklı boyutlarda desteklediğini gösterir niteliktedir. Ayrıca farklı paydaşların eğitsel oyunların öğrenci kazanımlarına yönelik ortak paydada görüşler bildirmeleri oyunların çocuklar üzerindeki katkılarını doğrular niteliktedir. Özellikle eğitsel oyunların dil becerilerinin gelişimini desteklemesine ilişkin sonuçlar alanyazında desteklenmektedir (Alemi, 2010; Blachowicz ve Fisher, 2004; Chou, 2014; Christakis, Zimmerman, ve Garrison, 2007; Rydland, 2009; Shuang ve Jin-xia, 2015; Wrigth, Betteridge ve Buckby, 2006). Türkçe dersi özelinde ise kullanılan eğitsel oyunların okuma, yazma, konuşma ve dinleme becerilerini geliştirmede ve öğrenmeyi kolaylaştırmada etkili olduğu belirtilmektedir (Alparslan, 2019; Arıcı, 2017; Aşcı, 2019; Gedik, 2017; Kara ve Akın, 2018). Bu doğrultuda Türkçe dersinde eğitsel oyun kullanımının dil becerilerinin gelişiminin desteklenmesi öncelikli olmak üzere öğrenci kazanımlarında oldukça etkili bir yöntem olduğu görülmektedir.

Araştırma sonuçlarının son boyutunu ise Türkçe dersinde eğitsel oyun kullanımının öğretmeöğrenme sürecine etkisi oluşturmaktadır. Araştırma sonuçları Türkçe dersinde eğitsel oyun kullanımının öğretim sürecinde verimliliği, ilgiyi ve anlamlandırmayı arttırdığı, diğer derslerle ve günlük hayatla ilişkilendirmenin sağlanmasına ve öğrenme ortamının sıradanlıktan çıkarılmasına yardımcı olduğunu göstermektedir. Analize dâhil edilen çalışmalar öğretmen ve öğrencilerin öğretme-öğrenme sürecinde eğitsel oyunların dikkat çekmede etkili olduğu ve öğretim sürecine aktif katılımı sağladığı yönünde ortak görüşleri olduğunu göstermektedir. Ayrıca araştırma eğitsel oyun kullanımının öğretme-öğrenme sürecinde öğretim programının yetişmesini güçleştirdiği ve ders sürelerinin oyunlar nedeniyle yetersiz kaldığı gibi öğretmenler tarafından bildirilen olumsuz sonuçları da sunmaktadır. Söz konusu olumsuz durum öğretmenlerin zaman yönetimi konusundaki yetersizliklerinin olası bir sonucu olarak değerlendirilebileceği gibi öğretmenlerin öğretim programlarının esnekliğinden yararlanamadıkları şeklinde de yorumlanabilir. Bu doğrultuda öğretmenlerin öğretim programları konusunda bilgi gereksinimlerinin karşılanması ve öğretim sürecinde farklı yöntem ve tekniklerin kullanılabilirliği üzerine hizmet içi eğitimlerle desteklenmesi önemli görülmektedir. Eğitsel oyunların Türkçe öğretiminde kullanımına yönelik meta-analiz, içerik analizi gibi üst düzey değerlendirme ve analizlerin yapılması yöntemin farklı boyutlardaki etkilerinin ortaya konmasını ve alandaki gelecek araştırmalara yöntem ve yönelim oluşturmasını sağlayacaktır. Ayrıca yöntemin etkileri üzerine özellikle dil becerileri bağlamında daha derinlemesine ve boylamsal araştırmalar gerçekleştirilmesi önerilmektedir.

\section{Araştırma ve Yayın Etiği}

Bu çalışmada "Yükseköğretim Kurumları Bilimsel Araştırma ve Yayın Etiği Yönergesi" kapsamında uyulması belirtilen tüm kurallara uyulmuştur. Yönergenin ikinci bölümü olan "Bilimsel Araştırma ve Yayın Etiğine Aykırı Eylemler" başlığı altında belirtilen eylemlerden hiçbiri gerçekleştirilmemiştir. 


\section{Yazarların Katkı Oranı}

Bu çalışma tek yazarlı olarak yazıımıştır.

\section{Çıkar Çatışması}

Bu araştırmada çıkar çatışması teşkil edebilecek herhangi bir durum ya da ilişki yoktur.

( ${ }^{*}$ Analize dâhil edilen çalışmalar)

\section{Kaynaklar}

Akcanca, N. ve Sömen, T. (2018). Öğretmen adaylarının eğitsel oyun tasarlama ve uygulama durumları. Turkish Studies, 13(27), 49-71.

Alemi, M. (2010). Educational games as a vehicle to teaching vocabulary. The Modern Journal of Applied Linguistics, 2(6), 425-438.

*Alevli, O. (2020). A game activity for improving vocabulary: Design, learn, reinforce. Journal of Inquiry Based Activities, 10(2), 146-156.

* Al-Khudhur, M. (2016). Yapım eklerinin öğretiminde eğitsel oyun temelli bir model önerisi: Kerkük Türkmenleri örneklemi (Yayımlanmamış yüksek lisans tezi). Gazi Üniversitesi Eğitim Bilimleri Enstitüsü, Ankara.

Alkış Küçükaydın, M. (2020). Eğitsel oyunların çocuk gelişiminde yeri ve önemi. M. Alkış Küçükaydın (Ed.), Illkokul eğitiminde eğitsel oyunlar ve güncel uygulamalar içinde (s.1-18). Ankara: Nobel Yayıncilık.

Alparslan, B. (2019). Eğitsel oyunların ilkokul 4. sınıf öğrencilerinin noktalama işaretlerini kullanma becerilerine etkisi (Yayınlanmamış yüksek lisans tezi). Akdeniz Üniversitesi Eğitim Bilimleri Enstitüsü, Antalya.

And, M. (1979). Çocuk oyunlarının kültürümüzde yeri ve önemi. Ulusal Kültür, 1(4), 42-66.

And, M. (2019). Oyun ve bügü Türk kültüründe oyun kavramı. İstanbul: Yapı Kredi Yayınları.

Arıcı, B. (2017). Eğitsel oyunların Almanya'da yaşayan Türk çocuklarının Türkçe öğrenme başarılarına etkisi (Yayımlanmamış doktora tezi). Atatürk Üniversitesi Eğitim Bilimleri Enstitüsü, Erzurum.

Aşcı, A. U. (2019) Eğitsel dijital oyunların 6. sınıf öğrencilerinin Türkçe dersi akademik başarılarına etkisi. Journal of International Social Research, 12(62), 932-941.

Aydın, T. (2014). Dil öğretimi ve oyun çoklu zeka teorisi ışığında. Dinbilimleri Akademik Araştırma Dergisi, 14(1), 71-83.

*Ayık, S. (2019). Erken yaşta yabancı dil olarak Türkçe öğretimi: Oyunların yazma becerisine etkisi (Yayımlanmamış doktora tezi). Hacettepe Üniversitesi Türkiyat Araştırmaları Enstitüsü, Ankara.

Aytaş, G. ve Uysal, B. (2017). Oyun kavramı ve sınıflandırılmasına yönelik bir değerlendirme. Manisa Celal Bayar Üniversitesi Sosyal Bilimler Dergisi, 15(1), 675-690.

*Babayiğit, Ö. ve Gültekin, M. (2019). İlkokuma yazma öğretiminde oyunla öğretim yöntemi uygulaması. Anadolu Journal of Educational Sciences International, 9(2), 450-483.

Batdı, V. (2019). Meta tematik analiz örnek uygulamalar. Ankara: Anı Yayıncılık.

Blachowicz, C.L.Z. ve Fisher, P. (2004). Putting the "fun" back in fundamental. J.F. Baumann ve E. J.Kame'enui (Ed.), Vocabulary instruction: Research to practice içinde (s. 210-238). New York: Guilford.

Boz, i. (2018). illkokul 4. sınıf Türkçe dersinde oyunla öğretim yönteminin akademik başarıya etkisi. Sosyal Bilimler ve Eğitim Dergisi, 1(1), 61-75.

Chou, M. (2014). Assessing English vocabulary and enhancing young English as a foreign language (EFL) learners' motivation through games, songs and stories. International Journal of Primary, Elementary and Early Years Education, 42(3), 284-297.

Christakis, D. A., Zimmerman, F. J. ve Garrison, M. M. (2007). Effect of block play on language acquisition and attention in toddlers: A pilot randomized controlled trial. Archives of Pediatrics \& Adolescent Medicine, 161(10), 967-71.

Coşkun, H., Akarsu, B. ve Kariper, İ. A. (2012). Bilim öyküleri içeren eğitsel oyunların fen ve teknoloji dersindeki öğrencilerin akademik başarılarına etkisi. Ahi Evran Üniversitesi Kırşehir Eğitim Fakültesi Dergisi, 1, 93-109. 
Çakmak, B. (2012). Absürd tiyatroda "oyun" kavramı ve Samuel Beckett'in oyun sonu ile Jean Genet'nin balkon adlı oyunlarına yönelik karşılaştırmalı bir inceleme. Tiyatro Araştırmaları Dergisi, 34, 4571.

*Erol, S. (2019). Yabancı dil olarak Türkçe öğretiminde eğitsel oyun kullanımı (Yayımlanmamış doktora tezi). İnönü Üniversitesi Eğitim Bilimleri Enstitüsü, Malatya.

*Ertem, i. S. (2016). Oyun temelli dijital ortamlar ve Türkçe öğretiminde kullanımına ilişkin sınıf öğretmenlerinin görüşleri. Akdeniz Eğitim Araştırmaları Dergisi, 10(20), 1-10.

Gedik, M. (2017). Ortaokul 2. sınıf öğrencilerinin okuma becerilerinin geliştirilmesinde eğitsel oyunların başarı ve kalıcılığa etkisi. Atatürk Üniversitesi Türkiyat Araştırmaları Enstitüsü Dergisi, 58, 453464.

Genç-Ersoy, B. (2020). Illkokul Türkçe eğitiminde eğitsel oyun kullanımı. M. Alkış Küçükaydın (Ed.), ilkokul eğitiminde eğitsel oyunlar ve güncel uygulamalar içinde (s. 53-71). Ankara: Nobel Yayıncilık.

Güneş, F. (2015). Oyunla öğrenme yaklaşımı. Turkish Studies, 10(11), 773-786.

Hazar, Z. ve Altun, M. (2018). Eğitsel oyunlara yönelik öğretmen görüşleri ve yeterliliklerinin incelenmesi. CBÜ Beden Eğitimi ve Spor Bilimleri Dergisi, 13(1), 52-72.

Huizinga, J. (2015). Homo ludens oyunun toplumsal işlevi üzerine bir deneme (M. A. Kılıçbay, Çev.). İstanbul: Ayrıntı Yayınları.

İnal, M. ve Korkmaz, Ö. (2019). Eğitsel oyunların öğrencilerin yabancı dil olarak Türkçe öğrenmeye dönük tutumlarına ve konuşma becerilerine etkisi. Ana Dili Eğitimi Dergisi, 7(4), 898-913.

Kalfa, M. (2014). Yabancılara Türkçe öğretiminde temel düzeydeki öğrencilerin eğitsel oyunlarla yazma becerilerinin geliştirilmesi. Hacettepe Üniversitesi Türkiyat Araştırmaları Dergisi, 20, 85-102.

Kapucu Seçkin, M. ve Çağlak, S. (2018). Fen bilgisi öğretmen adaylarının eğitsel oyun tasarlama ve sürece ilişkin görüşleri. Adıyaman Üniversitesi Sosyal Bilimler Enstitüsü Dergisi, 29, 536-573.

*Kara, S. (2018). Satranc-ı Urefa'nın eğitsel bir oyun olarak uyarlanmasının 6. sınıf öğrencilerinin kelime ögrretimine ve Türkçe dersi tutumlarına etkisinin incelenmesi (Siirt ili örneği) (Yayımlanmamış yüksek lisans tezi). Siirt Üniversitesi Sosyal Bilimler Enstitüsü, Siirt.

Karadağ, E. ve Çalışkan, N. (2008). Kuramdan uygulamaya ilköğretimde drama oyun ve işleniş örnekleriyle. Ankara: Anı Yayıncılık.

*Kaya, M. F. (2018). 4. sınıf öğrencilerinin temel dil becerilerinin geliştirilmesine yönelik tersyüz sınıf modelinin uygulanması (Yayımlanmamış doktora tezi). Eskişehir Osmangazi Üniversitesi Eğitim Bilimleri Enstitüsü, Eskişehir.

Ketterlinus, L. (2017). Using games in teaching foreign languages. West Point: United States Military Academy.

Kırbaş, ş. ve Koparan Girgin, G. (2018). İlkokulda eğitsel oyunlar tekniğinin öğretimdeki yerinin öğretmen görüşleri açısından incelenmesi. The Journal of Academic Social Science Studies, 65(1), 521-538. DOI: 10.9761/JASSS7355.

*Korucu, S. ve Kurtlu, Y. (2016). Türkçe öğretmenlerinin Türkçe derslerinde eğitsel materyal olarak oyun ve oyuncak kullanımına yönelik görüş ve önerileri. Turkish Studies, 11(9), 539-558.

Liberati, A., Altman, D. G., Tetzlaff, J., Mulrow, C., Gøtzsche, P. C., loannidis, J. P. ve Moher, D. (2009). The PRISMA statement for reporting systematic reviews and meta-analyses of studies that evaluate health care interventions: Explanation and elaboration. PLoS Medicine, 6(7), 1-28. DOI: 10.1371/journal.pmed.1000100.

Lillard, A. S., Matthew D. Lerner, E. J. Hopkins, R. A. Dore, Eric D. S., ve Carolyn M. P. (2013). The impact of pretend play on children's development: A review of the evidence. Psychological Bulletin, 139, 1-3.

Lincoln, Y. S. ve Guba, E. G. (1985). Naturalistic inquiry. Beverly Hills: SAGE Publications.

Mubaslat, M. (2012). The effect of using educational games on the students' achievement in English language for the primary stage. Erişim adresi: http://files.eric.ed.gov/fulltext/ED529467.pdf.

Önen, F., Demir, S. ve Şahin, F. (2012). Fen öğretmen adaylarının oyunlara ilişkin görüşleri ve hazırladıkları oyunların değerlendirilmesi. Ahi Evran Üniversitesi Kırşehir Eğitim Fakültesi Dergisi, 13(3), 299-318. 
*Öztemiz, S. ve Önal, H. İ. (2013). İlkokul öğrencilerinin oyun tekniği ile okuma alışkanlığı kazanmasına yönelik öğretmen görüşleri: Ankara Beytepe İlkokulu örneği. BEU SBE Dergisi, 2(1), 65-79.

Rydland, V. (2009). 'Whow - when I was going to pretend drinking it tasted coke for real!' secondlanguage learners' out-of-frame talk in peer pretend play: A developmental study from preschool to first grade. European Journal of Developmental Psychology, 6(2), 190-222.

*Sevim, S. (2019). Eğitsel oyunlar aracılığıyla kelime öğretiminin beşinci sınıf öğrencilerinin anlama becerilerine etkisi (Yayımlanmamış yüksek lisans tezi). Atatürk Üniversitesi Eğitim Bilimleri Enstitüsü, Erzurum.

Shuang, L. ve Jin- Xia, L. (2015). The application of games in English vocabulary teaching in kindergartens. Sino- US English Teaching, 12(8), 561-567.

*Şahin, F. (2019). Altıncı sınıf Türkçe dersi ses olayları konusunda geliştirilen eğitsel oyunun akademik başarıya etkisi (Yayımlanmamış yüksek lisans tezi). Balıkesir Üniversitesi Fen Bilimleri Enstitüsü, Balıkesir.

UNICEF. (2018). Learning through play: Strengthening learning through play in early childhood education programmes. Erişim adresi: https://www.unicef.org/sites/default/files/201812/UNICEF-Lego-Foundation-Learning-through-Play.pdf.

Ültay, N. ve Çalık, M. (2012). A thematic review of studies into the effectiveness of context-based chemistry curricula. Journal of Science Education and Technology, 26(6), 686-701.

Ünal, S., Çalık, M., Ayas, A. ve Coll, R.K. (2006). A review of chemical bonding studies: needs, aims, methods of exploring students' conceptions, general knowledge claims, and students' alternative conceptions. Research in Science \& Technological Education, 24(2), 141-172.

Yılmaz, A., Kırımoğlu, H. ve Yamanyurt, M. (2019). Beden eğitimi ve sınıf öğretmenlerinin eğitsel oyun oynatma öz yeterliliklerinin çeşitli değişkenler açısından incelenmesi (Van il örneği). Turkish Studies, 14(7), 4131-4144.

Weisberg, D. S., Zosh, J. M., Pasek, K. H. ve Golinkoff, R. M. (2013). Talking it up play, language devolopment and the role of adult support. American Journal of Play, 6(1), 39- 54.

Winnicott, D. W., (2013). Oyun ve gerçeklik (T. Birkan, Çev.). İstanbul: Metis Yayınları.

Wright, A., Betteridge, D. ve Buckby, M. (2006). Games for language learning. United Kingdom: Cambridge University Press.

Valipour, V. ve Aidinlou, N. A. (2014). The effect of language games on learning English listening speaking skills of Iranian pre-school students. Indian Journal of Fundamental and Applied Life Sciences, 4(2), 647-650.

Zhu, D. (2012). Using games to improve students' communicative ability. Journal of Language Teaching and Research, 3(4), 801-805.

Zigler, E. F., ve Bishop-Josef, S. J. (2004). Play under siege: A historical overview. E. F. Zigler, D. G. Singer, ve S. J. Bishop-Josef (Ed.), Children's play: The roots of reading içinde (s. 1-13). Washington: Zero to Three Press.

\section{Introduction}

\section{Extended Abstract}

There are studies in the literature that examine the effects of using educational games on language skills such as reading, writing, speaking, listening, developing vocabulary in teaching Turkish, as well as on student achievement, attitudes, and motivations. Although there are numerous quantitative studies in the literature, meta-analysis, meta-thematic analysis, content analysis, or systematic literature review studies that focus on using educational games in Turkish instruction have not been found. This study aims to develop an interpretive perspective by approaching the gap in the literature from a qualitative point of view.

Thus, it focuses on evaluating the available qualitative studies on the issue from a holistic point of view through the use of the meta-thematic analysis method. It is thought that this study will have an important place in the literature in terms of presenting qualitative studies in the literature from a holistic point of view. The study is also unique because it is the first one that examines the effects of using educational games in the Turkish course through meta-thematic analysis. 


\section{Method}

A meta-thematic analysis of the available qualitative studies on using educational games in teaching Turkish instruction was conducted. The studies were obtained via searches on Google Scholar, Higher Education Board Thesis Center, Ulakbim TR Index, Web of Science, ERIC, and ProQuest databases. The keywords educational games and teaching Turkish were used in the searches. Decisions to include and exclude the obtained works in the meta-thematic analysis were made subsequently. The criteria for inclusion were the studies' being on using educational games in teaching Turkish, their containing qualitative themes or raw qualitative data, and their consisting of full texts. As a result, 13 studies were included in the meta-thematic analysis. Through the analysis of the data through content analysis, themes and sub-themes were created.

\section{Results and Discussion}

The meta-thematic content analysis of the raw data resulted in the emergence of some different results. Some sub-themes in the teacher dimension attributed negative meanings to the use of the method such as it was not effective, it did not prepare students for exams, and it was difficult to use. Regarding the use of educational games during instruction, the findings were similar to the problems highlighted by the 2018 UNICEF report on learning through games which pointed out that teachers needed to have knowledge about game-based instructional methods, that educational games were considered inadequate in teaching academic concepts, that game-based instructional methods were not integrated into instructional programs, and that classroom environment for instruction with games was not adequate. The findings revealed not only the negative perspectives but also positive points of view on using the educational game method in Turkish classes.

All themes in the student dimension contained positive meanings. The fact that students highlighted the positive aspects of the method regarding the use of the educational game method in the Turkish course shows that its use had a positive impact on students.

As for the effects of educational games on teacher competencies, in all studies, teachers' lack of competence in using the method comes to the fore. It was found that teachers experienced difficulty in planning educational games and preparing for the lesson, adapting them to different levels of learning, finding games specific to the lesson content and outcomes, devising original games, and integrating educational games into their lessons. Besides, it was observed that in the teaching-learning process, teachers felt inadequacy in terms of class management, teaching at the level of students, and managing the teaching-learning process effectively. The results indicated that one of the reasons for the emerged lack of competence was due to inadequacies in pre-service teacher education. Some studies also show that senior teachers had not received education on the educational game method during their undergraduate education. In the studies analyzed, there are also findings which show that prospective teachers do not receive education on the use of educational games and game-based teaching at the undergraduate level.

The results show that using educational games in the Turkish course positively affects student achievement. In the studies analyzed, educational games seem to support students cognitively, sensorially, and socially. Besides, the fact that different stakeholders express similar views on student achievement through educational games confirms the positive contribution of educational games. In this respect, the use of educational games in the Turkish course is very effective on student achievement, especially in the development of language skills.

Research results show that the use of educational games in Turkish classes enhances efficiency, attention, and sense-making in the instructional process, helps students establish connections with other courses and daily life, and prevents monotony in the learning environment. The studies included in the analysis indicate that teachers and students believe that educational games are effective in maintaining focus in the teaching-learning process and ensure active participation in the instructional process. Research also reveals negative effects such as the use of educational games making it difficult to implement the curriculum thoroughly and the duration of the instruction time becoming shortened due to games. This negative effect may be considered both as a possible consequence of teachers' lack 
of effective time management skills and their inability to implement the curriculum flexibly. As a final remark, it may be stated that there is a need for more qualitative research to be conducted on the use of educational games in teaching Turkish, and it is recommended that more in-depth and longitudinal research be carried out on the effects of the method, especially in the development of language skills. 